\title{
Economic Efficiency of Employee Suggestion Systems in Manufacturing Enterprises
}

\author{
Robert KAGAN and Grzegorz KRZOS \\ Wroclaw University of Economics and Business, Wroclaw, Poland \\ Correspondence should be addressed to: Robert KAGAN; Robert.kagan@ue.wroc.pl \\ Received date:18 February 2020; Accepted date:15 July 2020; Published date: 4 March 2021 \\ Academic Editor: Zuzana Kirchmayer \\ Copyright (C) 2021. Robert KAGAN and Grzegorz KRZOS. Distributed under Creative Commons \\ Attribution 4.0 International CC-BY 4.0
}

\begin{abstract}
Full involvement of employees in improving enterprises and their processes is one of the flagship assumptions in modern management methods. A widely used solution supporting this approach is the employee suggestion systems (ESS), allowing the use of the intellectual potential and creativity of own staff. It is generally assumed that the main purpose of such systems is to increase employee involvement in enterprises improvement and to increase their sense of engagement and process ownership. Additionally, ESS generates savings and new revenues as a result of the implemented suggestions. However, in many cases, despite seemingly large number of improvement ideas submitted and implemented, they do not bring the assumed level of savings or do not generate the financial benefits expected by the company. In this paper, the authors present selected results of the research conducted on a group of 23 manufacturing companies from Poland, discuss resulting conclusions and research gaps and propose the direction for further work. The aim of the research was to find the answers for the following research questions: Do the applied ESS solutions allow to achieve the expected results (the level of savings), and how? Are there any key factors that influence the economic efficiency of ESS? and if these effects are missing or if there is an insufficient level of return on investment, which problems cause it?
\end{abstract}

Keywords: Employee Suggestion Systems, Continuous Improvement, Lean Management, Economic Efficiency

\section{Introduction}

Present-day enterprises naturally operate in conditions of a high business competitiveness. The emphasis on a high quality of products or services, short delivery times and low prices, combined with the requirement to keep the costs of own activities at a sufficiently low level entails the requirement for the most effective use of the company's own resources. It is assumed that a qualified and committed crew is one of such key resources, alongside of being an element of

Cite this Article as: Robert KAGAN and Grzegorz KRZOS (2021)," Economic Efficiency of Employee Suggestion Systems in Manufacturing Enterprises ", Journal of Innovation \& Business Best Practice, Vol. 2021 (2021), Article ID 936440, DOI: 10.5171/2021.936440 
strategy to build a company's long-term competitive advantage, which was pointed by both Womack (2011) and Balle (2019). Thus, the requirements for employees of such organizations are also growing, as they are not only expected to work effectively and efficiently, but also to be fully involved in the processes and individually propose ideas for process improvement, like Zupancic (2018) mentioned.

In this context, many authors e.g. Womack and Jones (1996), Womack (2011), or Jakubik and Kagan (2018) confirmed that it is recommended to notice the concept of Lean Management (LM), which from late 90s appears to be the critical way to achieve a competitive advantage of the enterprise. In the works of Womack and Jones (1996) and Harada (2015), the basis of LM is the elimination of all the possible waste, supported by internal processes improvement and employee involvement. The similar concept is repeated in the works of Imai (1986) and Balle (2017), where the success of LM implementation is defined based on strongly motivated and efficient workers on each organizational level of a company.

In a widespread approach, potential inefficiencies in business management are manifested by the presence of 7 main waste types supplemented by an additional, eighth waste type, i.e. unutilized employees' skills (Figure 1).

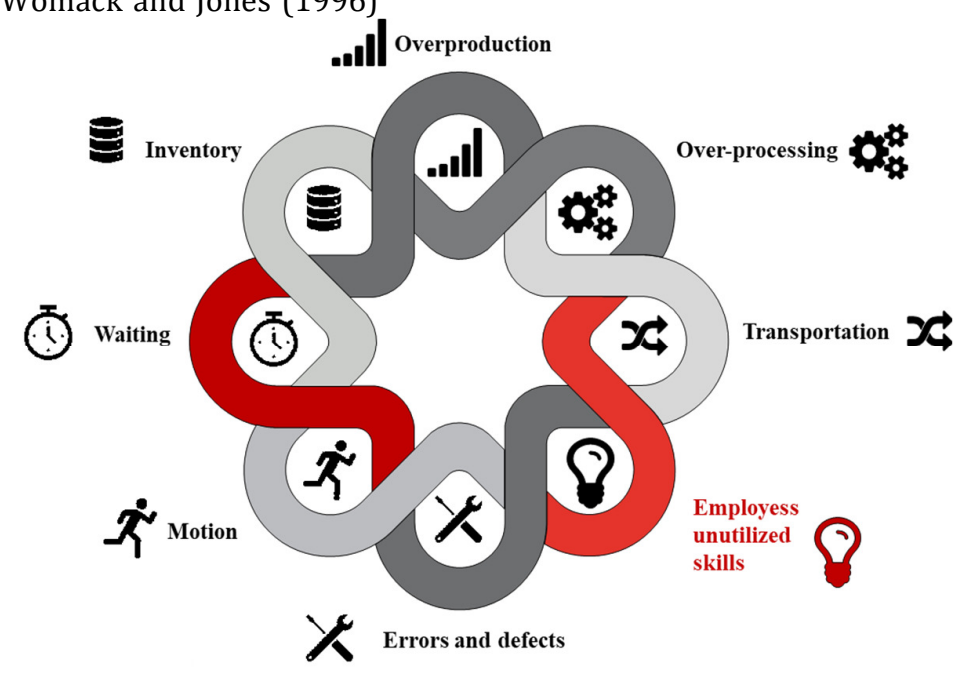

Fig. 1: 8 types of waste (sketch based on Womack and Jones (1996), graphics by PresentationGo.com)

In the vast majority of cases, the occurrence of these factors results in companies achieving lower-than-expected profits and observing reduced reliability and efficiency of the main and supporting processes, thus lowering their market competitiveness. This kind of conclusions can be found in many papers and case studies e.g. Womack (2011), Koch et al. (2012), Harada (2015) or Kagan and Jakubik (2019).

The waste of an employee's unutilized potential is a crucial issue here, because it may result in the decrease of an enterprise efficiency. It may lead to an underestimation of people's potential and therefore loss of many possible ideas and concepts that could otherwise be implemented and improved. It minimizes the possible ownership of areas and processes, self-engagement and subjectivity. For that reason, Balle et al. (2018) as well as Kagan and Jakubik (2019) mentioned that the emphasis should be put on the enterprise that is relying on development coming from workers' qualifications and their creative improvement ideas.

One of the forms of the abovementioned approach is the well-known concept of 
Kaizen Teian, originating from the Japanese management school and mentioned in the works of Japan Human Relations Association (1997), Lasrado (2013, 2015) and Krasiński (2017). The idea of Kaizen Teian is based on an employee suggestion system (ESS), relying on small and medium improvements suggested and implemented directly by the employees at their workplaces, processes and working areas. Most often, ESS exists in a form of formalized systems allowing employees to submit their process or product improvements suggestions, which after the supervisor's assessment can be relatively quickly implemented or rejected as either not fulfilling the planned criteria or inappropriate (Figure 2). Such systems are sometimes defined, for example by Japan Human Relations Association (1996) or Lasrado (2013), as systems of kaizen ideas or improving suggestions. As a rule, it is assumed that the company's employees have the greatest knowledge of the processes, machines or workstations they operate, thus gain wider opportunities to exert influence on their workplace, while employers receive an excellent source of benefits from reducing the company's operating costs or creating additional business potentials.

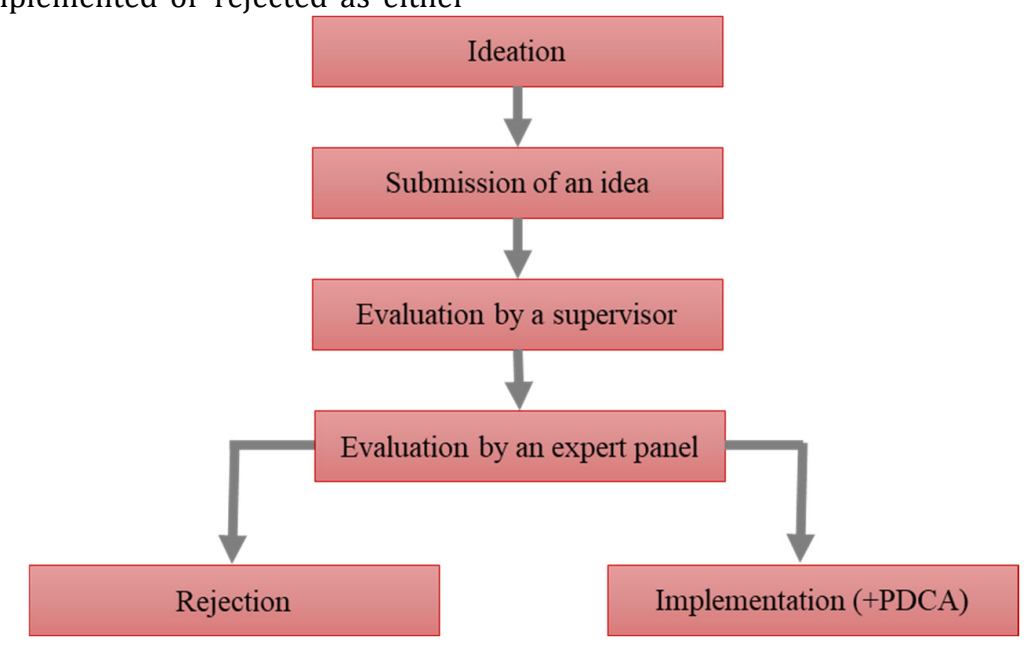

Fig. 2: Basic scheme of ESS and a flow of the submitted idea (based on Japan Human Relations Association (1997) and Gibs (2017))

\section{ESS - Two Approaches}

Practical implementation of ESS in the business environment allows to notice two main concepts of their operation. Imai (1986), Kejna (2014) and Dekier (2017) called it Japanese and American approaches. The Japanese approach is the dominant one and specific for the Japanese way of managing. It can be characterized by a high sense of teamwork and a well-established need to strive for excellence in action. It is based on the assumption that it is worth to submit and implement every single process or product improvement, even the smallest one having an inconsiderable influence on processes. The declared aim of ESS pointed by Imai (1986), Fairbank (2001) and Tucker (2012) is to enhance the operators' morale as well as their influence on management decisions, increasing the responsibility for their own workplace and processes. In itself, this approach assumes no primary emphasis on the economic effects of the system implementation or individual improvement ideas. Any resulting benefits and added value are treated as secondary.

What is also of high significance is the notion that the literature of the subject from Al-Noorachi (2016) and Vanharnata (2018) specifies the differences between kaizen and innovation and their implementation. The concepts assume that the true savings come from innovations, while kaizen ideas used in ESS are rather dedicated for daily and small process improvements (Table 1). The consequence of the abovementioned 
assumptions is the fact that ESS is considered a success only when certain number of ideas are implemented in relation to the number of the company's employees, which is to be an emanation of their involvement in the company's development - Robinson (214), Witt (2015) or Dekier (2017). At the same time, ESS effectiveness is often measured by e.g. the number of days from submitting the idea to its implementation or the percentage of employees contributing to the system, unfortunately overlooking the quality of the ideas.

Table 1: Comparison of kaizen and innovation concepts (based on Al-Noorachi (2016))

\begin{tabular}{|l|l|}
\hline \multicolumn{1}{|c|}{ Kaizen } & \multicolumn{1}{c|}{ Innovations } \\
\hline Adaptability & Creativity \\
\hline Small steps & Large steps \\
\hline $\begin{array}{l}\text { Every employee participates, general } \\
\text { preparation }\end{array}$ & Only chosen specialists participate \\
\hline Collective work & Individual work \\
\hline Small investments & Large investments \\
\hline Focus on details & Focus on the main issues \\
\hline People-oriented & Technology-oriented \\
\hline Relying on existing technology & Searching for new technologies \\
\hline Interdisciplinary groups & Employees + top management \\
\hline Strong feedback loop & Limited feedback loop \\
\hline & \\
\hline
\end{tabular}

From this perspective, most of the scientific studies focus largely on the technical aspects of the ESS, aimed at the different phases of their implementation and capability: from the development and study of the effectiveness of various ways of encouraging employees to submit ideas, through methods of material and nonmaterial motivation, to the specifics of the sheets for submitting such ideas and their translation into the number of improvement proposals, the methods of supporting the implementation of ideas, and the way of evaluating the proposals, as well as the methods of obtaining as many ideas as possible per one company employee.

The most often used efficiency indicators of such ESS according to Kagan and Jakubik (2019) are:

- The total number of ideas submitted by employees within a year number of ideas/employee)
- The percentage of the implemented ideas amongst all the submitted ones (the higher, the better)

- The average time from submitting the idea to its implementation (working or calendar days)

- The percentage of employees submitting the ideas [\%]

The second trend in the design and operation of ESS, described in the book by Imai (1986) is the so-called American approach, which emphasizes the enterprise's economic benefits resulting from the implementation of improvement ideas, thus strongly changing the function of the goal of the foundation of such a system. This is because the measurable effects of the ESS, which is supposed to provide the company with certain savings or increase other economic benefits resulting from the implementation of number of improvements, come to the fore. Often emphasized, one of the features of this approach is a common use of financial motivators, which are supposed to encourage employees to be more and more 
active, and therefore, by default, associate the idea with money. A lot of research has been done on the American approach e.g. Leach (2006) or Lasrado (2015), but these methods are often boiled down to the control of the ways of financial motivation or the examination of the relations between inducing and generating ideas. For example, Lasrado (2016) and Gibbs (2017) mention that the obligation of submitting a minimum of two ideas quarterly per employee results in enhancing the level of savings. The impressive case studies of Townsend (2009) and Lasrado (2013) showed a significant relation between the level of savings coming from ESS and the levels of return on investments (even more than billion dollars in 5:1 ratio).

The superiority of one of the above concepts is questionable. According to Dekier (2017), the Japanese approach is chosen by many Western companies, assuming that the system itself is a strategic tool for employees' engagement in the company's operations, and that the improvement of processes is in the employees' interest as well as their responsibility. Other companies, in turn, focus on the measurable effects of using suggestion systems, sometimes even going as far as sharing a large extent of the improvement-induced financial benefits with employees.

\section{Definition of Research Problem}

Although the ESS systems are not a new solution, their implementation and operation processes have not been yet examined deeply in Poland. A research study on 201 manufacturing and service enterprises in Poland made by Grycuk and Dekier (2014) shows that the dominant motive for the ESS implementation is the desire to improve the company (56\%), which is to manifest itself in the improvement of processes, improvement of work organization by reducing waste, shortening the time of realization of customers' orders and reducing the emerging technical problems (Fig. 3).

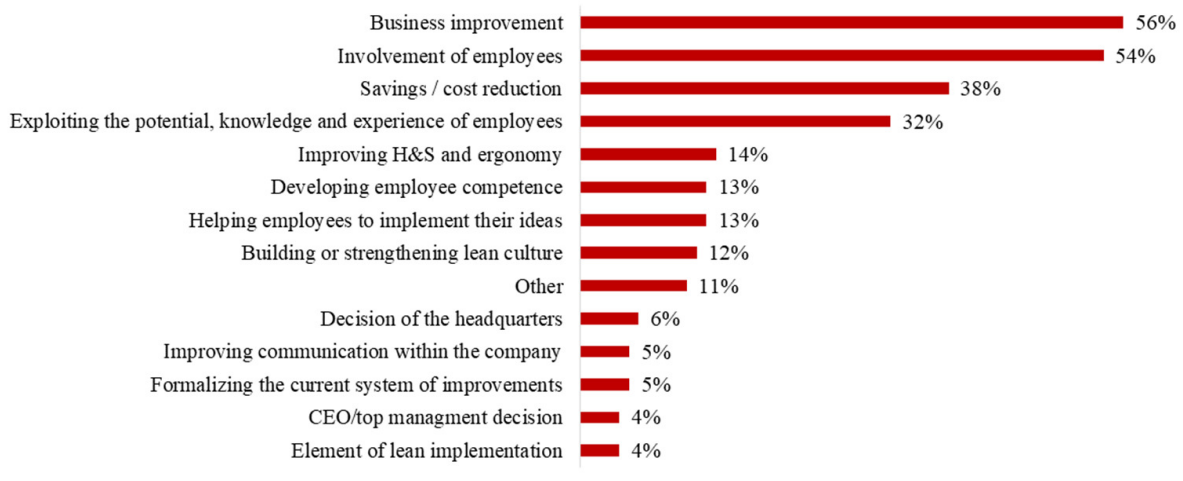

Fig 3:Reasons for implementing ESS in Polish enterprises (based on Grycuk and Deikier 2014)

On the second place, the respondents mentioned the desire for a broader and stronger involvement of their employees (54\%). The third place went directly to the intention to achieve measurable savings, reduce costs and avoid excessive expenses $(38 \%)$.
This way, it seems that ESS implemented in Poland could be considered as a hybrid model of the Japanese and American approaches, emphasizing the need for employees' involvement and anticipation of measurable effects. What is surprising is that over $85 \%$ of the responded companies apply additional reward systems for employees submitting improvement ideas. On the other hand, only $21 \%$ of the 
respondents measure the results based on the advantages coming from the improvements. What is more -various methods of measurement are applied (i.e. by the amount - after 12 months period following the implementation of the idea by the equivalent of full-time savings etc.). It is difficult to compare results from different companies and to draw conclusions.

Based on these research gaps, in 2015-2019 in-depth, an ESS case study examination was carried out at 23 manufacturing companies in Poland. The main goal was to check the implemented ESS solutions, especially their measurable gains and ESS economic efficiency. The research questions were also sought to determine whether and how the ESS solutions achieve the expected results (savings or additional revenues), whether there are any key factors influencing the economic efficiency of such ESSs, and, in the absence of such effects or effects below the assumed level of return on investment, which problems stand most often in the way of the expected ESS efficiency.

\section{Research work and Selected Results}

The first stage of the research was done on 23 selected manufacturing enterprises from Poland, which implemented the structured ESS. The companies represented 6 main types of manufacturing industry: automotive, home appliances, machinery, electronics, food and metal industries.

The exploration research work had been done by a direct interview method and the respondents were individuals directly responsible for the ESS implementation and maintenance in their companies (positions like Lean Manager, Lean Leader, Lean Coordinator, Continuous Improvement Specialist and Lean Management Specialist).
The questionnaire consisted of 31 questions (22 closed and 9 open questions) and was structured around three main areas:

- ESS effectiveness: What are the outcomes of ESS? How are these outcomes measured, (evidenced and controlled in the organization)? What is the level of savings or new revenues generated as a result of the implemented suggestions? What are the indictors in use? Where are the dominant benefit areas coming from employee suggestions? etc.

- ESS capability: How is the system organized? How is the idea submitted? How are the evaluation and feedback processes structured and maintained? What are the kinds of rewards used for the submitted and implemented suggestions? How does the management support and motivate all the employees to participate in the continuous improvement processes?

- ESS barriers: What are the main problems and largest difficulties in implementing ESS? How did companies manage and address the organizational impediments?

The obtained information were both qualitative and quantitative. The chosen answers reflected the respondents' experiences and knowledge about Lean Management and ESS. In 7 out of 23 enterprises, the respondents did not take a part in ESS implementation from the very beginning, but they followed the system maintenance on a daily basis.

$74 \%$ of the examined enterprises were considered large companies, the remaining 6 enterprises belonged to SMEs. A distribution of the surveyed companies by employment level is shown in Figure 4. 


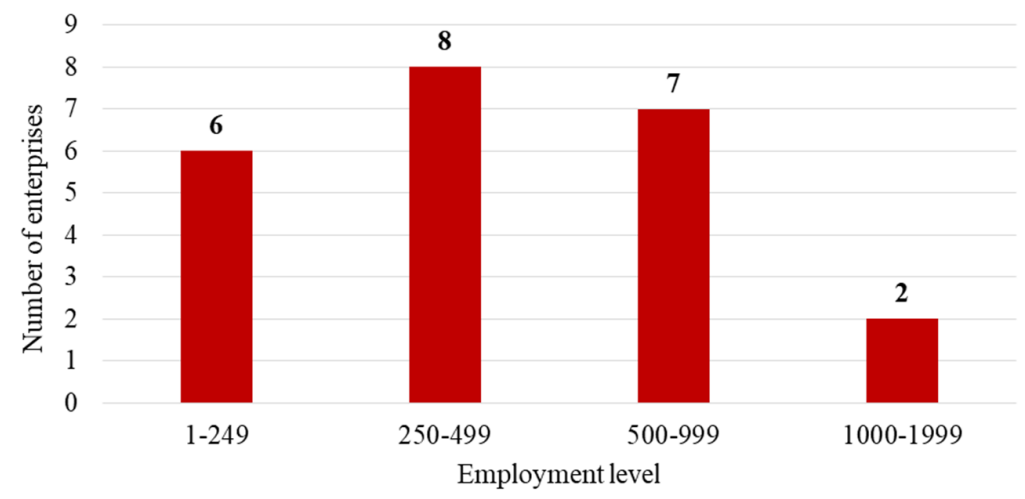

Fig. 4: Number of surveyed enterprises by number of employees

In every single case, the ESS has been performing in a formalized and structured way for at least a year and a half. The initial phase was devoted for a research on the field of a maturity level according to Lasardo-Gomiscek method described by Lasardo (2015). It allows 5 areas of operation of the ESS to be examined, and each of them to be evaluated according to an appropriate scoring scale. The areas are as

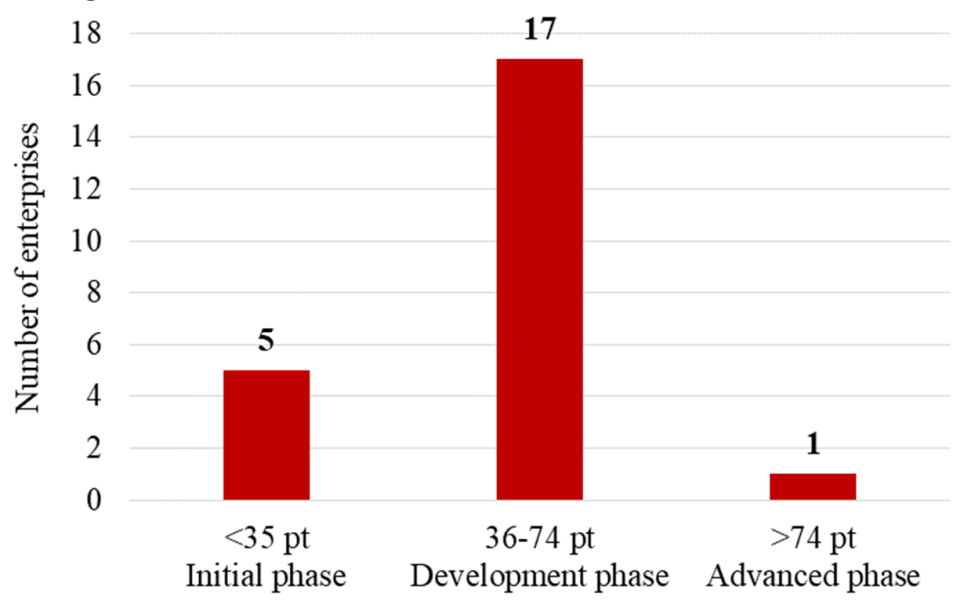

Fig. 5: Number of surveyed enterprises in terms of the degree of maturity of the system following: leadership and management support, system properties, system efficiency, organizational support and system limitations. Out of the surveyed companies, nearly $74 \%$ received the "Development phase" rating (average level). The phase of advanced development was achieved by only one of the examined systems (Fig 5).

Robert KAGAN and Grzegorz KRZOS, Journal of Innovation \& Business Best Practice, DOI: $10.5171 / 2021.936440$ 
Respondents were asked to determine three dominant benefits that motivate the enterprise to implement and maintain ESS. The detailed results are presented in Figure 6. Sixty-nine answers were obtained. Respondents declared their reasons as follows: willingness to improve the processes and products (74\% of all the answers), direct achievement of measurable and quantifiable financial benefits thanks to the ideas submitted as part of the ESS (70\%), and strengthening the employee involvement (48\%).

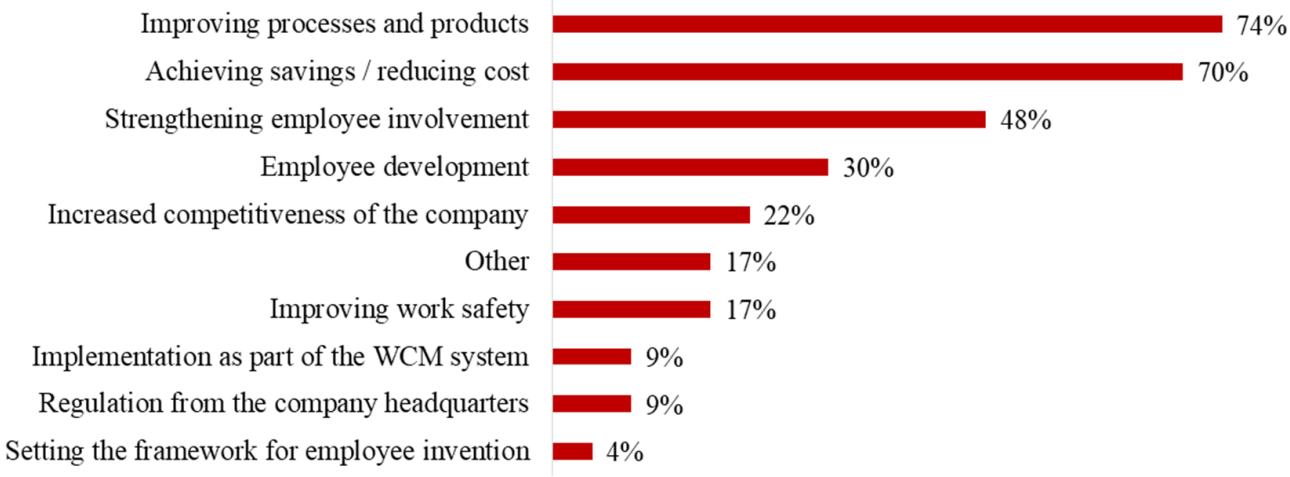

Fig 6. Declared reasons for the implementation of ESS in the surveyed enterprises

The question: Measuring the economic efficiency of ESS has a key role for my

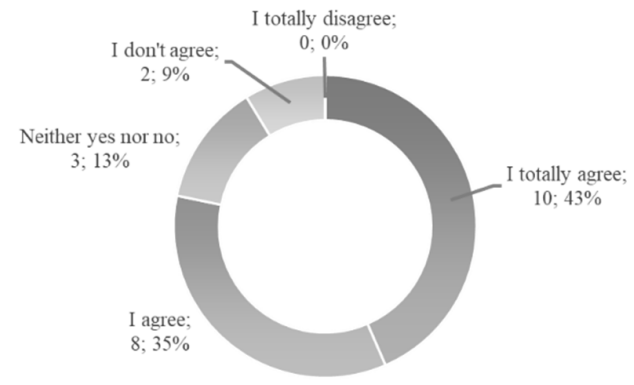

company turned out to be very important (Fig 7).

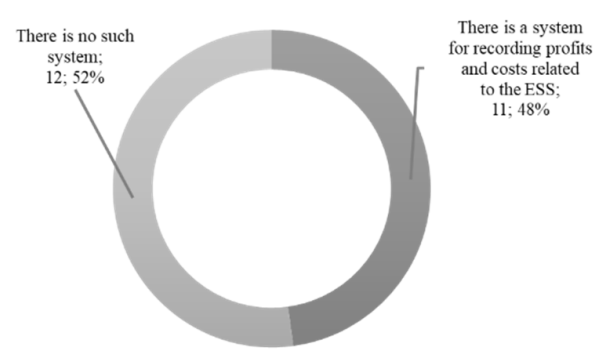

Fig 7. Effectiveness of ESS in the surveyed enterprises - expectations versus reality

In Likert scale, $78 \%$ of the questioned enterprises chose the option: I strongly agree, or I agree. It points to the high significance level of ESS operation. On the other hand, only $43 \%$ of the enterprises turns out to possess the measurement tools. It shows the broad gap between the declarations and the practical system maintenance (Fig 7).
The examined enterprises use various scales and ways to calculate the benefits coming from the implemented systems during the measurement of the financial results of ESS operation. A few main ways are listed below:

- The entire growth of company's revenues or savings, achieved thanks to the submitted ideas, without considering the costs of their 
implementation and ESS maintenance as a whole, which are considered only in the general company's costs,

- The level of measurable company-wide savings made thanks to the ideas, taking into account direct costs, but not taking into account the translation of a given idea into areas which were not directly related to the impact of a given solution (i.e. a small structural change in the assembled product results in material savings and increases the efficiency of the process by $1.5 \%$, and these benefits are properly recalculated, however, the same idea also eliminates the need for servicing and calibration of pneumatic wrenches from the assembly stations, which is no longer taken into account for the calculations),

- The level of financial benefits from improvement ideas according to the departments where the idea was first implemented. Despite such cost allocation, the costs of ESS operation are included partly in the overall enterprise costs and partly in the costs of operation of the departments involved,

- The level of the net return on the reported and implemented ideas considering the 12 months period from the time of the idea's full implementation,

- The level of the net benefits obtained from the implemented idea within 24 or 36 months depending on the scale of the proposed solution and the impact of the change on the process or product,

- The level of measurable savings calculated as the sum of benefits coming from the implementation on the scale of the whole enterprise, considering only the ideas giving more than 500 PLN (about 125 USD) net per one idea (this means the elimination of minor ideas from the list, the sum of which, however, may give a significant value, currently overlooked in the system ),

- The equivalent of the full-time posts eliminated thanks to the performed actions,

- Additionally, applied company's financial benefit indicator per one implemented idea.

The abovementioned examples make the situation even more complicated, because companies consider their general costs, or they additionally consider the cost of idea improvement. Consequently, the lack of a common ground prevents finding the correlation between the solutions of ESS and the scale of obtained measurable benefits.

It should be emphasized that 6 out of 23 examined companies (23\%) declare caution in calculating the direct benefits of implementing employees' improvement ideas. They refer it to the fear of the entire systems' stigmatization where only financially beneficial ideas are demanded. They suggest that the ideas that do not bring benefits, are underestimated. Nevertheless, those ideas are very valuable as well (i.e. in the area of work safety, ergonomics).

The next issue concerns three areas, where the financial benefits are particularly significant. The question was addressed to 11 companies declaring the application of such indicators. The results are shown in Table 2.

Table 2: Areas of highest economic impact of improvement ideas in the surveyed companies

\begin{tabular}{|l|c|}
\hline \multicolumn{1}{|c|}{ Area of financial impact of ESS } & $\begin{array}{c}\text { Percentage of } \\
\text { companies indicating } \\
\text { the area of influence } \\
\text { [in \%] }\end{array}$ \\
\hline Efficiency of production processes & 91 \\
\hline Product quality & 55 \\
\hline On-time delivery & 45 \\
\hline
\end{tabular}

Robert KAGAN and Grzegorz KRZOS, Journal of Innovation \& Business Best Practice, DOI: $10.5171 / 2021.936440$ 


\begin{tabular}{|l|c|}
\hline Level of stocks of semi-finished products and materials & 27 \\
\hline Lead time & 27 \\
\hline Other & 27 \\
\hline Efficiency of supporting processes & 18 \\
\hline Consumption of materials & 9 \\
\hline
\end{tabular}

There is a clear indication of three main areas, which are production process efficiency (indicated by $91 \%$ of the surveyed companies), product and service quality and on-time delivery of products and services to customers. This is directly related to the thematic scope of the submitted employees' ideas. However, the areas of "safety at work" and "ergonomics of the workplace" are, by default, not included in the list, which, although indicated as frequent subjects of submitted improvement ideas, their translation into financial results is not counted by companies. Table 3 shows the other indicators, which refer to ESS in enterprises.

Table 3: ESS indicators used in the surveyed companies

\begin{tabular}{|l|c|}
\hline \multicolumn{1}{|c|}{ ESS indicators } & $\begin{array}{c}\text { Percentage } \\
\text { of } \\
\text { companies } \\
\text { using the } \\
\text { indicator } \\
\text { [\%] }\end{array}$ \\
\hline Number of ideas submitted by employees (total per company) & 100 \\
\hline Number of implemented ideas (total per company) & 100 \\
\hline Percentage ratio of ideas submitted to implemented & 100 \\
\hline Number of ideas submitted and implemented by the company's & 78 \\
\hline organisational departments & 78 \\
\hline Average number of ideas per employee & 48 \\
\hline Number of ideas waiting in line for implementation (delay scale) & 48 \\
\hline The level of savings from ideas per company and per areas & 39 \\
\hline Number of ideas in priority areas (e.g. safety or quality) & 39 \\
\hline Level of financial (or point) rewards for employees for implemented ideas & 35 \\
\hline Time from notification to idea evaluation and feedback & 35 \\
\hline Time from submission to implementation of the idea & 22 \\
\hline Percentage of employees involved in the ESS & 17 \\
\hline Level of financial benefit per improvement idea & \\
\hline
\end{tabular}

A certain group of indicators commonly used in all the companies can be observed. They concern the number of submitted ideas. The indicators showing the financial influence of improvement ideas are rarely mentioned (22\% and $17 \%)$.

The respondents were also asked to list the four most important problems and limitations of a proper operation of ESS in their company. Overall, 92 answers were obtained, where the percentage of the answers is shown in Figure 8. The quality of ideas and processes show the anticipated problems in achieving measurable benefits (70\%), or make it difficult or impossible for supervisors to make an accurate decision to reject the application or accept it for 
implementation $(61 \%)$ or cause a large number of ideas to be put forward by employees, but they are insufficient in quality (52\%).

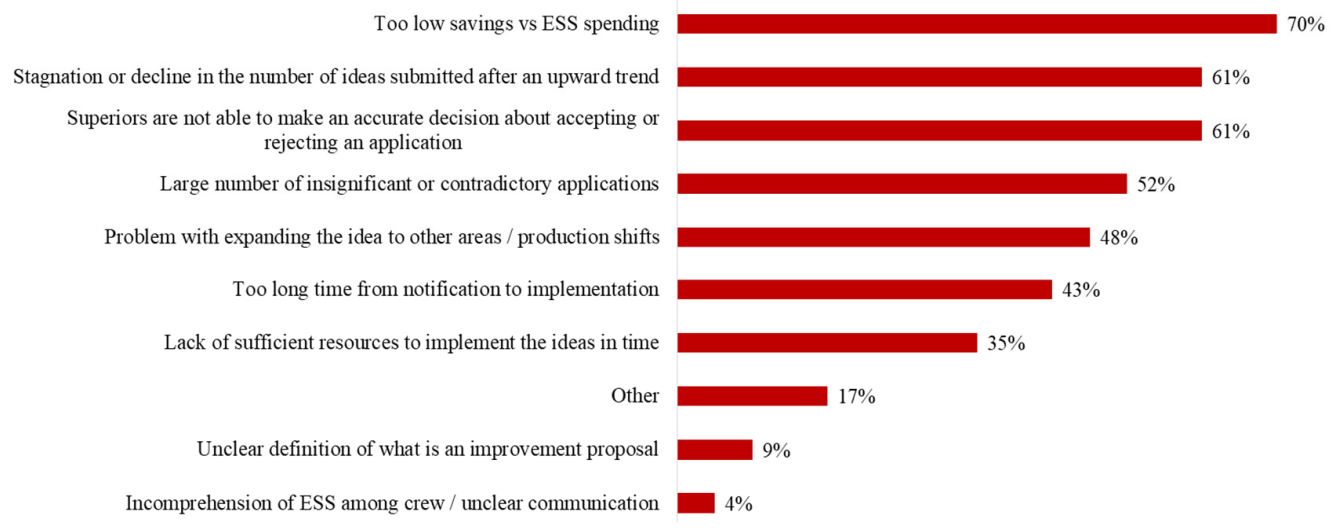

Fig 8. Problems of companies in the operation of ESS declared in the survey

Even though all the companies reported various problems in the everyday operations and maintenance of ESS, only 3 out of 23 enterprises analyzed the situation to investigate the source of the problem. 20 out of 23 companies performed only interim corrective actions. This action gives a little chance to draw conclusions for a structural improvement of ESS and to generalize recommendations.

\section{Discussion and conclusions}

The research was done on the group of 23 manufacturing enterprises in Poland. Even though manufacturing companies differ from service companies, the results may be generalized to formulate some common conclusions and to ask even more research questions.

1. Based on the described research probe and previous research work from Grycuk (2014), it may be assumed that the dominant reasons to implement and maintain ESS in Polish companies are both the willingness to encourage the employees in constant improvement and maximizing their sense of identification with the company (Japanese approach) as well as the expectation of achieving measurable effects from such a system and translating it into business results of the company (American approach).

2. The ESS solutions commonly used in the surveyed companies put the emphasis on the number of submitted ideas, the greatest increase in the percentage of the ideas implemented to the submitted, the broad involvement of the company's employees in the system and shortening the time from idea submission to its implementation. The indicators used in these companies also focus on these aspects. Only a few of the companies have metrics allowing to measure the financial translation of the implemented ideas within the ESS into the economic effectiveness of the system itself or the whole enterprise in general. This makes it difficult or impossible to take appropriate corrective actions to increase such effectiveness. Further research in the area should be designed and conducted.

3. The measures of the economic efficiency of ESS do not share the common ground, which hinders creating the cause and effect relationship and discovering the correlation between the parts of ESS and economic results of ESS in a 
research probe. Largely, the way of calculating the measurable economic benefits do not consider the obtained additional indirect benefits coming from the implementation of employee ideas in the remaining company's areas, limiting the calculations to financial savings only.

The literature research like Leach (2006), Arthur (2017) or Dekier (2017) do not clearly suggest how to measure the efficiency of ESS. Many indicators are mentioned in the literature:

- The increase of the final customer satisfaction and the increase in the quality and efficiency of the processes,

- The increase in the safety level of employment and trust towards an employer,

- The increase in employee engagement,

- The increase in the revenue and savings level.

4. Currently used models of calculating the economic efficiency of ESS do not solve the problem of properly quantifying the scope of the benefits, which are related to process influence, i.e. in the form of the quality-focused preventions, enabling faster problem-solving processs. The mentioned aspect has been already discussed by Trenkner (2015), but the subject has not been fully tackled.

5. Among the problems with the operation of the ESS in the enterprises mentioned by the respondents, the first place $170 \%$ of the indications) was given to underreported savings in terms of investment in the entire ESS. The dissatisfaction was most often related to the costs incurred for the implementation and maintenance of the system, implementation of the improvement ideas themselves and the analysis and corrective actions of the already implemented solutions (without taking into account the ideas aimed at the improvement of work safety, which were not evaluated).

At the same time, $52 \%$ of the respondents indicated problems with applications that propose mutually exclusive or too trivial solutions from the perspective of improving the process correctness. Potential causes were seen in the poor communication of objectives to the employees, or irregularities in the way of implementing motivational solutions to submit ideas, as well as the low level of employees' knowledge of continuous improvement.

By combining these two indications, it can be concluded that the problem in accomplishing a certain economic efficiency of the ESS is not the small number of the submitted ideas, but their quality, which does not allow for achieving an adequate rate of return on a running ESS.

6. The interesting phenomena is the stagnation effect (or even its decrease) in the number of the submitted ideas at a particular time of ESS development (it occurs in 61\% of the companies). This issue is relatively poorly examined and described in the subject literature. The sources of those events are supposed to come from the slowly developed competence level of the employees in the scope of the constant improvement and its methods and solutions of Lean Management, which causes persistent "exhaustion of ideas" among the company's crew. The other causes may be also: the indirect negative correlation between the decrease in the number of ideas and the long time from reporting the idea to its realization, and the insufficient resources to accomplish all of the ideas, which was pointed by Jakubik and Kagan (2015), and Kagan and Jakubik (2019). 
7. The additional aspect of ESS operations in the context of anticipated economic efficiency of the system is assigning the goals, creating the adequate area and the atmosphere in the company to operate effectively and to communicate these goals to the employees. In the context of the survey results, which indicate that $26 \%$ of the surveyed companies refrain from directly declaring their expected financial benefits, reasoning it by their concerns regarding the lack of submission of valuable improvement ideas from areas that are difficult or impossible to accurately quantify. It seems important to configure the ESS in such a way as to give an equal priority to ideas with financial translation and also to ideas outside such an impact pool.

The results collected from the abovementioned research and a review of the literature on the subject indicate clear gaps in the field of knowledge about ESS, especially in terms of the impact of various factors on the economic efficiency of such systems. It is assumed that there is such an ESS model that will not only allow to achieve a large number of ideas submitted by employees, but also a large translation of these ideas into measurable economic results for the system itself and, therefore also for the entire enterprise.

Such studies will require the determination of an algorithm for measuring the economic efficiency of the ESS, which can be universally applied under given boundary conditions to various types of enterprises, and thus enable finding a correlation between such economic efficiency and factors affecting it.

\section{References}

- Al-Noorachi, M. (2016), 'Innowacje i koncepcja Kaizen szansą dla rozwoju biznesu (Innovation and Kaizen Concept as an Opportunity for Business Development)', Przedsiębiorczość i Zarządzanie, vol. 17 issue 9, 143-154.
- $\quad$ Arthur, J.B. and Aiman-Smith, L. (2017), 'Gainsharing and Organizational Learning: An Analysis of Employee Suggestions Over Time', The Academy of Management Journal, 44(4), [Online], [Retrieved May 20, 2019], https://journals.aom.org/doi /10.5465/3069413

- Balle, M., Chartier, N., Coignet, P., Olivencia, S., Powell and D., Reke, E. (2019), The Lean Sensei. Go See Challenge, Lean Enterprise Institute, Boston.

- Balle, M., Jones, D., Chaize, J. and Fiume, 0. (2017), The Lean Strategy. Using Lean to Create Competitive Advantage, Unleash Innovation and Deliver Sustainable Growth, McGraw Hill, NY.

- Dekier, L. (2017), Zastosowanie systemu sugestii w przedsiębiorstwach zarządzanych zgodnie $\mathrm{z}$ metodą Lean Management (Application of Suggestion System in Enterprises Managed in Accordance with the Lean Management Method), Doctoral dissertation, Poznan.

- Fairbank, J. and Williams, S.D. (2001), 'Motivating Creativity and Enhancing Innovation through Employee Suggestion System Technology', Creativity and Innovation Management, vol.10 no.2, 68-74.

- Gibbs, M., Neckermann, S. and Siemroth, Ch. (2017), 'A field experiment in motivation employee ideas', The Review of Economics and Statistics, vol. 99(4), 577-590.

- Grycuk, A. and Dekier, L. (2014), Employee Suggestion Schemes, Lean Management Association of Poland, Wroclaw.

- Harada, T. (2015), Management Lessons from Taiichi Ohno, McGraw Hill, NY.

- Imai, M. (1986), Kaizen: The Key To Japan's Competitive Success, McGrawHill, NY.

- Jakubik, M. and Kagan, R. (2018), 'Właściciel firmy w świecie Lean zrozumieć swoją rolę dla własnych korzyści (Business owner in the Lean world - understand your role for your own benefits)', Proceedings of the $18^{\text {th }}$ International Lean Management 
Conference, June 2018, Wroclaw, Poland.

- Jakubik, M. and Kagan, R. (2015), 'Three ways to destroy your suggestions system', Planet Lean The Lean Global Network Journal, [Online], [Retrieved December 20, 2019], https://planetlean.com/kaizen-suggestions-leanchallenges/

- Japan Human Relations Association (1997), Kaizen Teian 1: Developing Systems for Continuous Improvement Through Employee Suggestions, Productivity Press, NY.

- $\quad$ Kagan, R. and Jakubik, M. (2019), Na rozdrożach Lean Management (On the Crossroads of Lean Management), Lean Enterprise Institute Poland, Wrocław.

- Kejna, Sz. (2014), 'Metodyka pozyskiwania i przetworzenia dodatkowych informacji do celów zarządczych poprzez analizę systemów sugestii opartych na filozofii kaizen (The Methods of Acquiring and Processing Additional Managerial Information through Analysis of Kaizen-Based Employee Suggestion Systems)', Acta Universitas Lodziensis, Folia Oeconomica 2(300).

- Koch, T., Horbal, R., Kagan, R., Sobczyk, T. and Plebanek, S., (2012), '10 Commandments for the Boss of a Company Implementing Lean Philosophy', Management and Production Engineering Review, vol.3, 62-78.

- Krasinski, M. (2017), System kaizen w budowaniu trwałej przewagi konkurencyjnej (Kaizen system in building lasting competitive advantage), Wydawnictwo Uniwersytetu Ekonomicznego we Wrocławiu, Wroclaw.

- Lasrado, F., Arif, M., Rizvi, A. and Urdzik, C. (2016), 'Critical success factors for employee suggestion schemes: a literature Review', International Journal of Organizational Analysis, vol.24 no.2, 315-339.

- $\quad$ Lasrado, F. and Gomiscek, B. (2015), 'A tool to measure maturity of an employee suggestion scheme', Management and Production Engineering Review, vol.6 no.2, 4-13.
- $\quad$ Lasrado, F., Arif, M. and Rizvi, A. (2015), 'The determinants for sustainability of an employee suggestion system', International Journal of Quality \& Reliability Management, vol. 32 no.2, 182-210.

- Lasrado, F. (2013), 'An Overview of Employee Suggestion Schemes: The Past, Present and the Future', Skyline Business Journal, vol.3 issue 1.

- Leach, D. and Stride, Ch. (2006), 'The Effectiveness of Idea Capture Schemes', International Journal of Innovation Management, vol.10 no.3, 325-350.

- Tucker, A. and Singer, S. (2012), Key Drivers of Successful Implementation of an Employee Suggestion-Driven Improvement Program, Harvard Business School Working Paper, no.12112.

- Robinson, A. and Schroeder, D., (2014), The Idea-Driven Organization: Unlocking the Power in Bottom-Up Ideas, Berrett-Koehler Publishers, Oakland, CA.

- Townsend, W. (2009), 'The Use of Suggestion Program Metrics for the Measurement of Innovation', Perspectives in Business, vol.6 no.1.

- Trenkner, M. and Truszkiewicz, B. (2015), 'Zaangażowanie pracowników w ciągłe doskonalenie - studium przypadku' (Employees Commitment for Continuous Improvement - Case Study), Nauki o zarządzaniu, no. 3(24), 149-164.

- Vanharanta, O. (2018), 'Whose responsibility is it anyway? Competing narratives of suggestion system change', Creativity and Innovation Management, vol.27, issue 3, 244-254.

- Witt, J. and Witt, T. (2015), Der Kontinuierliche Verbesserungsprozess (The Continuous Improvement Process), Winmuehle Verlag, Hamburg.

- Womack, J. (2011), Gemba Walks, Lean Enterprise Institute, Boston.

- Womack, J. and Jones D, (1996), Lean Thinking: Banish Waste and Create Wealth in Your Corporation, Simon \& Schuster, NY.

- Zupancic, M. (2018), 'Employees: Invisible Added Value of a Company', Our Economy, vol. 64(2), 52-61. 